\title{
Moderate hypothermia during cardiopulmonary bypass increases intramyocardial synthesis of heat shock protein 72
}

\author{
Ma Qing, $M D^{a, e}$ \\ Jaime F. Vazquez-Jimenez, $M D^{\text {b,e }}$ \\ Kathrin Schumacher, $\mathrm{MD}^{\mathrm{a}, \mathrm{e}}$ \\ Ranjit S. Bhardwaj, $\mathrm{PhD}^{\mathrm{c}, \mathrm{e}}$ \\ Bernd Klosterhalfen, $\mathrm{MD}^{\mathrm{c}, \mathrm{e}}$ \\ Ralf Minkenberg ${ }^{\mathrm{d}, \mathrm{e}}$ \\ Bruno J. Messmer, $M D^{\mathrm{b}, \mathrm{e}}$ \\ Götz von Bernuth, $\mathrm{MD}^{\mathrm{a}, \mathrm{e}}$ \\ Marie-Christine Seghaye, $\mathrm{MD}^{\mathrm{a}, \mathrm{e}}$
}

Objectives: This study was undertaken to test the hypothesis that the myocardial protective effect of moderate hypothermia during cardiopulmonary bypass involves upward regulation of heat shock protein 72 .

Methods: Sixteen young pigs were randomly assigned to a temperature regimen during standardized cardiopulmonary bypass of normothermia or moderate hypothermia (temperatures $37^{\circ} \mathrm{C}$ and $28^{\circ} \mathrm{C}$, respectively, $\mathrm{n}=8$ per group). Myocardial probes were sequentially sampled from the right ventricle before and during bypass and 6 hours after bypass. Messenger RNA encoding for heat shock protein 72 was assessed by competitive reverse transcriptase-polymerase chain reaction, and heat shock protein 72 synthesis was assessed by Western blot and immunohistochemical methods. Induction of apoptosis was assessed by gene expression of apoptosis-regulating proteins (Bcl-xL, Bak, and Fas) according to competitive reverse transcriptase polymerase chain reaction. Apoptotic cells were identified with an in situ apoptosis-detection kit (terminal deoxynucleotidyl transferase-mediated deoxyuridine triphosphate nick-end labeling) in combination with morphologic criteria. Necrotic cells were detected by standard histologic methods.

ology a and Thoracic and Cardiovascular Surgery, ${ }^{\mathrm{b}}$ the Institutes of Pathology ${ }^{\mathrm{c}}$ and Biostatistics, ${ }^{\mathrm{d}}$ and University Hospital, ${ }^{\mathrm{e}}$ Aachen University of Technology, Aachen, Germany.

Supported by a grant of the Deutsche Forschungsgemeinschaft (DFG SE 912/2-1).

Received for publication Nov 29, 2001; revisions requested Feb 5, 2002; revisions received Feb 21, 2002; accepted for publication March 4, 2002.

Address for reprints: Ma Qing, MD, Department of Pediatric Cardiology and Congenital Cardiac Diseases, German Heart Center Munich, Technical University of Munich, Lazarettstrasse 36, D. $80636 \mathrm{Mu}-$ nich, Germany (E-mail: ma@dhm.mhn.de).

J Thorac Cardiovasc Surg 2002;124:724-31

Copyright ( $(2) 2002$ by The American Association for Thoracic Surgery

$0022-5223 / 2002 \$ 35.00+0 \quad \mathbf{1 2 / 1 / 1 2 4 4 9 8}$

doi: $10.1067 / \mathrm{mtc} .2002 .124498$
Results: Moderate hypothermia rather than normothermia was associated with earlier and higher gene expression and synthesis of heat shock protein 72 in the myocardium during and after cardiac surgery. In the hypothermia group both heat shock protein 72 and the messenger RNA encoding it were detected as soon as 30 minutes after initiation of bypass and before aortic clamping, whereas in the normothermia group they were not detected before aortic clamping. Immunohistochemical methods showed localization of heat shock protein 72 in the cardiomyocytes, endothelial cells, and macrophages. Although the percentage of necrotic cells in the myocardium was lower in the hypothermic group, the induction of apoptosis groups.

Conclusions: These results suggest that the myocardial protective effect of moderate hypothermia during cardiopulmonary bypass involves upward regulation of heat shock protein 72 and inhibition of necrosis but not of apoptosis. regulatory proteins and the percentage of apoptotic cells did not differ between the 
I $\mathrm{n}$ a recent experimental study, we showed that moderate hypothermia during cardiopulmonary bypass $(\mathrm{CPB})$ attenuates the systemic inflammatory reaction associated with cardiac surgery and provides organ protection by inducing an anti-inflammatory cytokine balance. ${ }^{1}$ In this respect, the myocardium of an animal subjected to moderately hypothermic CPB shows less histologic and ultrastructural signs of cell damage and cell death than does that of a control animal operated on under normothermia. ${ }^{2}$ The mechanisms controlling cell damage and cell death are complex. They involve natural protective processes that repress the production of proinflammatory and harmful proteins and control cell death by inhibiting the necrosis or the apoptosis pathways. ${ }^{3}$ Both apoptotic and necrotic forms of cell death are induced by death domain receptors. Whereas necrosis is strongly inflammatory and devastating to neighboring tissues, however, apoptosis is a noninflammatory, self-regulating process that could limit tissue damage and contribute to the removal of activated inflammatory cells., ${ }^{4,5}$ Apoptosis is related to the expression of the surface receptor Fas ${ }^{6}$ and activation of the caspase pathway, ${ }^{7,8}$ which is controlled by the Bcl-2 protein family of both apoptosis-inhibiting (BclxL) and apoptosis-promoting proteins (Bak).

A well-known mechanism providing cellular protection is the induction of heat shock proteins (HSPs). HSPs are molecular chaperones expressed after cellular insult ${ }^{9}$ that exert a protective effect by refolding damaged proteins. ${ }^{9}$ Experimental studies suggest that HSP-70 could participate in the control of apoptosis by refolding damaged repressors of the apoptotic pathway. ${ }^{10}$ Inducers of the heat shock response include, among others, heat treatment and inflammatory mediators. ${ }^{11}$ HSP-70 is the member of the HSP family that has been most extensively studied, and HSP-72, its inducible form, is exclusively expressed during stress. ${ }^{12}$ A recent in vitro study has suggested that HSP-70 is also induced by cold, ${ }^{13}$ but to date the question of whether hypothermic CPB would induce HSP-72 expression has not been addressed. This experimental study was designed to test the hypothesis that the myocardial protective effect of moderate hypothermia during $\mathrm{CPB}$ is related to upward regulation of HSP-72.

\section{Material and Methods}

This study was conducted according to the guidelines of the German Animal Protection Law ensuring humane care and was approved by the supervising state agency for animal experiments. Sixteen female pigs weighing $38 \pm 0.5 \mathrm{~kg}$ (mean $\pm \mathrm{SEM}$ ) were randomly assigned to a temperature group during CPB $(n=8$ per group): normothermia, with a temperature of $37^{\circ} \mathrm{C}$, and moderate hypothermia, with a temperature of $28^{\circ} \mathrm{C}$.

General anesthesia was uniform and consisted of a combination of ketamine and pentobarbital given in repeated doses as necessary. After endotracheal intubation, the lungs of the animals were mechanically ventilated with an air and oxygen mixture (inspired oxygen fraction 0.5 ). Core temperature was monitored with an esophageal temperature probe (probe 16561; Datex-Ohmeda Division, Instrumentarium Corp, Helsinki, Finland). Cefotiam (50 $\mathrm{mg} / \mathrm{kg}$ ) was given intravenously for antibiotic prophylaxis. Catheters were placed in the carotid artery and jugular vein as well as in the left atrium.

CPB equipment was uniform and consisted of a roller pump inducing a nonpulsatile flow, a disposable pediatric hollow-fiber oxygenator, a hard-shell cardiotomy reservoir, an arterial blood filter, and a bubble trap. The extracorporeal perfusion circuit was primed with a crystalloid solution. Bovine lung heparin (400 $\mathrm{IU} / \mathrm{kg}$ ) was given for systemic anticoagulation. Both caval veins, the aorta, and the left atrium were cannulated, allowing the institution of total CPB. Total duration of CPB was set at 120 minutes for all animals; this included 30 minutes of perfusion during which animals operated on in moderate hypothermia were cooled down to $28^{\circ} \mathrm{C}$ with a heat exchanger, 60 minutes of perfusion during which the aorta was crossclamped, and 30 minutes of perfusion during which pigs undergoing hypothermic CPB were rewarmed to $37^{\circ} \mathrm{C}$. In the normothermia group, perfusion was performed at $37^{\circ} \mathrm{C}$. CPB was conducted with a flow index of $2.7 \mathrm{~L} /\left(\mathrm{min} \cdot \mathrm{m}^{2}\right.$ body surface area) in all animals, with a target mean systemic arterial pressure of $60 \mathrm{~mm} \mathrm{Hg}$. Immediately after aortic crossclamping, cardioplegia was achieved by injection of a single dose of cold $\left(4^{\circ} \mathrm{C}\right)$ crystalloid cardioplegic solution (Bretschneider solution, $30 \mathrm{~mL} / \mathrm{kg}$ ) into the aortic root. Additional topical cooling of the myocardium was performed by application of $500 \mathrm{~mL} 4^{\circ} \mathrm{C}$ cold saline solution. Myocardial temperature during CPB was monitored with a needle temperature probe placed into the ventricular septum (Temperature Sensing Catheter; Medtronic HemoTec, Inc, Englewood, Colo). At the end of CPB, anticoagulation was reversed by protamine. Mediastinal drains were placed, and the chest was closed.

\section{Postoperative Care}

The lungs of the pigs were mechanically ventilated until the end of the experiment (6 hours after sternal closure). Postoperative monitoring included continuous registration of heart rate and rhythm, mean arterial blood pressure, and left atrial pressure (LAP). Esophageal temperature and urinary output were also recorded. Target values for mean arterial blood pressure, LAP, and urinary output during the whole postoperative period were about $60 \mathrm{~mm} \mathrm{Hg}, 5$ to $9 \mathrm{~mm} \mathrm{Hg}$, and more than $1.5 \mathrm{~mL} /(\mathrm{kg} \cdot \mathrm{h})$, respectively. Inotropic support and diuretic treatment consisting of dopamine and furosemide, respectively, were adapted accordingly, as was volume substitution with a Ringer's lactate solution.

Tissue samples for reverse transcriptase (RT)-polymerase chain reaction (PCR) and Western blot were taken from the apex of the right ventricle before institution of $\mathrm{CPB}$, before aortic crossclamping, and before opening of the aortic clamp. Additional sample was taken immediately post mortem for RT-PCR, Western blot, histologic study, and immunohistochemical study. Samples for RT-PCR and Western blot were rapidly excised, snap-frozen in liquid nitrogen, and then stored at $-70^{\circ} \mathrm{C}$ until processing. For standard histologic and immunohistochemical studies, tissue specimens were fixed in $10 \%$ buffered formalin, embedded in paraffin, and cut in $4-$ to $6-\mu \mathrm{m}$ thick serial sections. 
TABLE 1. Primers used for polymerase chain reaction amplification

\begin{tabular}{|c|c|c|c|}
\hline Product & Orientation & $\begin{array}{c}\text { Gene bank } \\
\text { accession No. }\end{array}$ & 5'-3' Sequence \\
\hline HSP-72 & $\begin{array}{l}\text { Sense } \\
\text { Antisense }\end{array}$ & X68213 & $\begin{array}{l}\text { CCTTCACCGACACCGAGC } \\
\text { TTGAAGTAGGCAGGCACGGT }\end{array}$ \\
\hline$\overline{B c l-x L}$ & $\begin{array}{l}\text { Sense } \\
\text { Antisense }\end{array}$ & AJ001203 & $\begin{array}{l}\text { GGTGGTTGACTTTCTCTCCTAC } \\
\text { CAAAAGTGTCCCAGCCGCC }\end{array}$ \\
\hline$\overline{B a k}$ & $\begin{array}{l}\text { Sense } \\
\text { Antisense }\end{array}$ & AJ001204 & $\begin{array}{l}\text { TTTACCGCCATGAGCAGG } \\
\text { TAGCCGAAGCCCAGAAGAG }\end{array}$ \\
\hline Fas & $\begin{array}{l}\text { Sense } \\
\text { Antisense }\end{array}$ & AJ001202 & $\begin{array}{l}\text { CTGTCAGCCATGCCCTC } \\
\text { GCCCATAACCAGTGTAGG }\end{array}$ \\
\hline$\overline{\beta \text {-actin }}$ & $\begin{array}{l}\text { Sense } \\
\text { Antisense }\end{array}$ & U07786 & $\begin{array}{l}\text { GGACTTCGAGCAGGAGATGG } \\
\text { GCACCGTGTGGCGTAGAGG }\end{array}$ \\
\hline
\end{tabular}

\section{Counting of Necrotic and Apoptotic Cells}

Four serial sections from the myocardial probe were stained with hematoxylin and eosin. Morphologic criteria used to determine cell necrosis were cell swelling, disruption of cell membrane and cell architecture, lysis of the cell organelles and the nuclei, and hypereosinophilia. ${ }^{14}$ A cell was considered necrotic if at least one of these criteria was met. Necrotic cells were counted in 5 different fields of each slide by light microscopy at $\times 400$ magnification by two different investigators (M.Q., B.K.) blinded to the temperature group. Their counts differed by less than $10 \%$. An average of 1000 cells were counted per slide; results are reported as the average of the percentages of necrotic cells counted by each investigator.

Detection of apoptotic cells was performed on replicates of the paraffin sections with terminal deoxynucleotidyl transferasemediated deoxyuridine triphosphate nick-end labeling assay (ApopTag; Serologicals Corporation, Norcross, Ga) according to the manufacturer recommendations. For quantification of apoptosis, samples with labeled fluorescence staining were investigated with confocal laser scanning microscopy (Laser Scan Microscopy LSM 410 invert with Axiovert 135M; Carl Zeiss, Oberkochen, Germany). Apoptotic cells in 12 different fields were counted (an average of 1000 cells were counted per slide). Data were reported as the percentage of apoptotic cells, as averaged from the counts of both investigators. ${ }^{2}$ Adjacent hematoxylin and eosin-stained sections were examined to assess typical morphologic findings of apoptosis (cell shrinkage, chromatin condensation and margination, and apoptotic bodies. ${ }^{14}$

\section{Heat Shock Protein 72 Assay}

HSP-72 immunohistochemical assay was performed on paraffinembedded tissue sections with the IHC mouse kit (InnoGenex, Inc, San Ramon, Calif). Briefly, sections were pretreated with a solution of Peroxide Block to inhibit endogenous peroxidase activity and incubated with Power Block Reagent to block nonspecific protein binding. Subsequently, they were incubated with the monoclonal mouse anti-human HSP-72 antibody (1:200; StressGen Biotechnologies Corp, Victoria, British Columbia, Canada) for 2 hours at room temperature. After rinsing with phosphatebuffered saline solution plus $0.1 \%$ polysorbate, the slides were incubated for 30 minutes with the secondary antibody. The slides were rinsed with phosphate-buffered saline solution and incubated for 20 minutes in streptavidin-horseradish peroxidase conjugate. The color reaction was developed in aminoethyl carbazole substrate. Specimens were counterstained with Mayer hematoxylin. Appropriate positive and negative controls were used for primary antibody. Cellular localization of HSP-72 was analyzed with the Quantimet 600 image analyzer system (Leica Microsystems Nussloch GmbH, Nussloch, Germany).

\section{Reverse Transcriptase-Polymerase Chain Reaction}

Total RNA was extracted with the RNeasy Mini Kit (QIAGEN $\mathrm{GmbH}$, Hilden, Germany). RNA ( $3 \mu \mathrm{g}$ ) was reverse transcribed to complementary DNA with random hexamers. With pig-specific primers for HSP-72, Bcl-xL, Bak, Fas and $\beta$-actin (Table 1), complementary DNA products were coamplified by PCR. Thirtyfive cycles for Bcl-xL, Bak, and Fas and 38 cycles for HSP-72 were performed after an initial denaturation at $95^{\circ} \mathrm{C}$ for 2 minutes: 30 seconds at $94^{\circ} \mathrm{C}, 30$ seconds at $58^{\circ} \mathrm{C}\left(60^{\circ} \mathrm{C}\right.$ for HSP-72), and 30 seconds at $72^{\circ} \mathrm{C}$. PCR products were subjected to electrophoresis in $1.8 \%$ agarose gel, stained with ethidium bromide, and photographed. The predicted lengths of amplification products for the genes encoding HSP-72, Bcl-xL, Fas, Bak, and $\beta$-actin were 324, $289,523,372$, and 233 base pairs, respectively. Results are presented as the ratio of the band intensities of the RT-PCR product to the corresponding messenger RNA (mRNA) encoding $\beta$-actin (Bio-Rad Multi-Analyst, Bio-Rad Laboratories Inc, Hercules, Calif).

\section{Western Blot}

Myocardial samples were homogenized in lysis buffer (1-mol/L tris[hydroxymethyl]aminomethane hydrochloride, $\mathrm{pH}$ 7.4, 0.5 $\mathrm{mol} / \mathrm{L}$ ethylenediaminetetraacetic acid, $10 \%$ deoxycholat, and $10 \%$ nonidet P-40) containing the following protease and phosophatase inhibitors: pepstatin A $(2 \mu \mathrm{g} / \mathrm{mL})$, leupeptin $(5 \mu \mathrm{g} / \mathrm{mL})$, aprotinin (5 $\mu \mathrm{g} / \mathrm{mL})$, and phenylmethylsulfonyl fluoride $(1 \mathrm{mmol} / \mathrm{L})$. Samples were incubated for 30 minutes at $4^{\circ} \mathrm{C}$ and centrifuged at $14,000 \mathrm{~g}$ for 10 minutes at $4^{\circ} \mathrm{C}$. Protein quantities were determined with a modified Bradford assay (Bio-Rad). Sodium dodecyl sulfate-polyacrylamide gel electrophoresis was conducted with the Laemmli buffer system on $12 \%$ polyacrylamide gels. Proteins (50 $\mu \mathrm{g}$ for each lane) separated on gels were transferred to a polyvi- 
TABLE 2. Esophageal and myocardial temperatures before, during, and after CPB in pigs operated on under moderate hypothermia or normothermia

\begin{tabular}{|c|c|c|c|c|c|c|}
\hline \multirow[b]{2}{*}{ Time point } & \multicolumn{3}{|c|}{ Esophageal temperature } & \multicolumn{3}{|c|}{ Myocardial temperature } \\
\hline & $28^{\circ} \mathrm{C}$ & $37^{\circ} \mathrm{C}$ & $P$ value & $28^{\circ} \mathrm{C}$ & $37^{\circ} \mathrm{C}$ & $P$ value \\
\hline Before CPB & $36.0 \pm 0.3$ & $36.1 \pm 0.2$ & $>.2$ & $35.3 \pm 0.1$ & $35.4 \pm 0.2$ & $>.2$ \\
\hline Before aortic crossclamping & $28.2 \pm 0.3$ & $35.9 \pm 0.7$ & .005 & $28.1 \pm 0.3$ & $34.6 \pm 0.4$ & $<.001$ \\
\hline Immediately after cardioplegia & $27.9 \pm 0.05$ & $37.1 \pm 0.3$ & .002 & $12.7 \pm 0.6$ & $13.9 \pm 1.7$ & $>.2$ \\
\hline $\begin{array}{l}10 \text { min after aortic crossclamping } \\
30 \text { min after aortic crossclamping } \\
60 \text { min after aortic crossclamping }\end{array}$ & $\begin{array}{l}27.9 \pm 0.05 \\
27.9 \pm 0.05 \\
28.4 \pm 1.4\end{array}$ & $\begin{array}{l}37.3 \pm 0.4 \\
37.5 \pm 0.5 \\
35.8 \pm 1.1\end{array}$ & $\begin{array}{l}.002 \\
.002 \\
.012\end{array}$ & $\begin{array}{l}18.0 \pm 1.7 \\
23.9 \pm 1.1 \\
28.4 \pm 1.4\end{array}$ & $\begin{array}{l}18.8 \pm 1.7 \\
27.7 \pm 2.2 \\
30.3 \pm 1.5\end{array}$ & $\begin{array}{l}>.2 \\
.081 \\
>.2\end{array}$ \\
\hline Declamping of aorta & $27.9 \pm 0.05$ & $37.4 \pm 0.3$ & .002 & $29.2 \pm 1.9$ & $33.0 \pm 1.5$ & .141 \\
\hline End of CPB & $35.6 \pm 0.3$ & $36.9 \pm 0.2$ & .029 & $34.9 \pm 0.3$ & $35.4 \pm 0.8$ & $>.2$ \\
\hline $6 \mathrm{~h}$ after $\mathrm{CPB}$ & $35.9 \pm 0.4$ & $37.1 \pm 0.6$ & .019 & $36.3 \pm 0.8$ & $38.2 \pm 0.8$ & $>.2$ \\
\hline
\end{tabular}

nylidene difluoride membrane (Millipore GmbH, Eschborn, Germany) with a semidry electroblotting apparatus. Binding of the primary and secondary antibodies was performed in phosphatebuffered saline solution ( $\mathrm{pH} 7.5$ ) containing $0.1 \%$ polysorbate 20 overnight at $4{ }^{\circ} \mathrm{C}$ (primary antibodies) and for 1 hour at room temperature (secondary antibody). Primary antibodies used in immunoblotting were mouse anti-human HSP-72 antibody (1:1000 dilution, monoclonal; Stressgen Biotechnologies) and mouse antihuman $\beta$-actin antibody (1:2000 dilution, monoclonal; Sigma, St Louis, Mo). Polyclonal antimouse horseradish peroxidase-conjugated secondary antibodies (1:2000 dilution; DAKO Diagnostika $\mathrm{GmbH}$, Hamburg Germany) were used to reveal the immunoreactive bands with the ECL chemiluminescence system according to the manufacturer instructions (Amersham Biosciences Europe GmbH, Freiburg, Germany). Signals for HSP-72 and $\beta$-actin produced bands of $70.5 \mathrm{kd}$ and $43 \mathrm{kd}$, respectively. All protein signals for HSP-72 were normalized for $\beta$-actin signals that were developed on the same blot (NIH imaging 1.61b8. software; Bio$\mathrm{Rad})$.

\section{Statistical Analysis}

Results are expressed as mean \pm SEM. Data were analyzed by analysis of variance with adjustment of $P$ values by the Scheffé procedure for repeated comparisons. The $t$ test was used for the pairwise comparison of mean values. Correlation analysis was performed with the Pearson correlation coefficient. Data were analyzed with SPSS statistical software package (SPSS Software $\mathrm{GmbH}$, München, Germany).

\section{Results}

\section{Esophageal and Myocardial Temperatures}

Table 2 summarizes esophageal and myocardial temperatures during and after CPB. Esophageal temperatures during and after CPB were lower in pigs operated on under moderate hypothermia than in the other group. In contrast, intergroup differences in myocardial temperature during and after CPB were not observed or could have been due to chance, with the exception of that measured before crossclamping of the aorta.

\section{Hemodynamics}

LAPs measured 1 and 4 hours after CPB tended to be lower in the hypothermia group than in the normothermia group $(\mathrm{LAP} 7.1 \pm 0.7 \mathrm{~mm} \mathrm{Hg}$ vs $9.3 \pm 0.8 \mathrm{~mm} \mathrm{Hg}$ and $7.3 \pm 0.6$ $\mathrm{mm} \mathrm{Hg}$ vs $9.5 \pm 0.9 \mathrm{~mm} \mathrm{Hg}$, respectively, $P=.050)$. Heart rate, mean arterial pressure, and diuresis did not differ between the groups (data not shown).

\section{Synthesis of Heat Shock Protein 72}

HSP-72 expression was not detected in the myocardium at either the mRNA or the protein level before institution of CPB but was detected in all animals 6 hours after CPB. At that time, both HSP-72 gene expression and HSP-72 concentration were higher in pigs operated on under moderate hypothermia than in those operated on under normothermia (Figures 1 and 2). In the former group, HSP-72 expression was detected at both mRNA and protein levels as soon as 30 minutes after institution of $\mathrm{CPB}$, before crossclamping of the aorta, and increased further during myocardial ischemia but no more after the operation. In contrast, in the normothermia group HSP-72 expression was not detected at either the mRNA or the protein level before CPB but was only detected at the end of the period of myocardial ischemia (90 minutes after institution of $\mathrm{CPB}$ ) and did not increase further after the operation (Figures 1, $A$, and 2, $A$ ). Intramyocardial gene expression and concentrations of HSP-72 during and after CPB were higher in animals operated on under moderate hypothermia than in those operated on under normothermia (Figures 1, B, and 2, B). Expression of mRNA encoding $\beta$-actin was not affected by CPB.

\section{Heat Shock Protein 72 Immunohistochemical Detection}

In all animals, HSP-72 was present in the myocardium sampled 6 hours after CPB and was localized in cardiomyocytes, macrophages, and endothelial cells (Figure 3). 
A

HSP72 mRNA

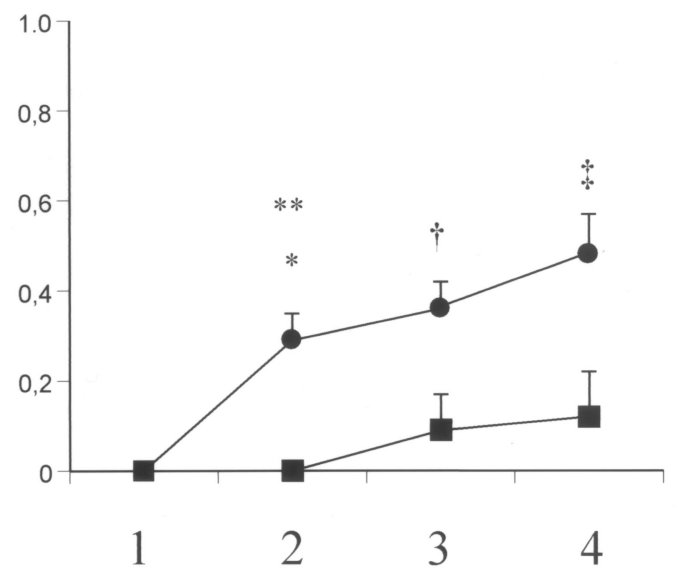

B

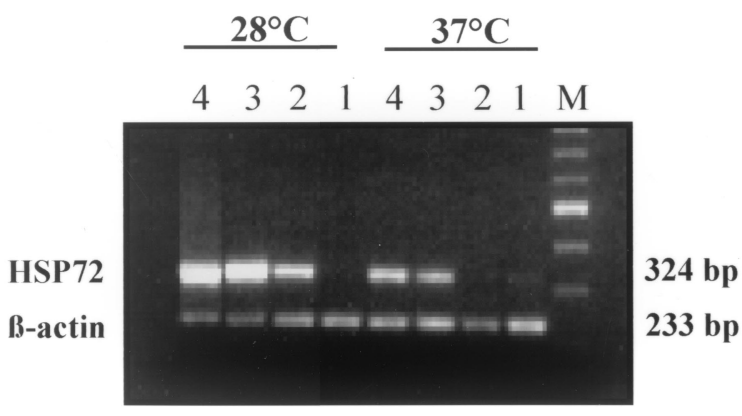

Figure 1. A, Expression of mRNA encoding HSP-72 in myocardium before CPB (1), before aortic crossclamping (2), before removal of aortic clamp (3), and 6 hours after CPB (4) in pigs operated on under moderate hypothermia (temperature $28^{\circ} \mathrm{C}$, circles) and under normothermia (temperature $37^{\circ} \mathrm{C}$, squares). Results are shown as ratio of mRNA encoding HSP-72 to that encoding $\beta$-actin detected by RT-PCR. Data points represent mean value; error bars represent SEM. Double asterisk indicates difference versus prebypass value in hypothermia group $(P=.042)$. Asterisk indicates $\boldsymbol{P}<.001$ between groups; dagger indicates $\boldsymbol{P}=.002$; double dagger indicates $\boldsymbol{P}=.007$. B, Effect of core temperature on myocardial expression of mRNA encoding HSP-72 detected by RT-PCR. Results are representative for 8 independent experiments in each group (moderate hypothermia $28^{\circ} \mathrm{C}$, normothermia $37^{\circ} \mathrm{C}$ ). $M$, Molecular weight markers; $b p$, base pairs.

\section{Necrosis}

The percentage of necrotic cells in the myocardium was lower in pigs operated on under hypothermia $(0.23 \% \pm$ $0.13 \%$ ) than in those operated on under normothermia $(2.57 \% \pm 0.57 \%, P=.002)$.

\section{Apoptosis}

In all animals, mRNA encoding Fas, Bak, and Bcl-xL was not detectable in the heart before institution of CPB but was detectable 6 hours after $\mathrm{CPB}$, without any intergroup differences (Table 3). At that time apoptotic bodies and apoptotic cells were also present in the myocardium of animals of both groups and averaged $0.82 \% \pm 0.47 \%$ in the animals operated on under hypothermia and $0.33 \% \pm 0.24 \%$ in those operated on under normothermia $(P>.2)$.

\section{Discussion}

In this study, moderate hypothermia during CPB was associated with intramyocardial upward regulation of HSP-72 expression and with reduction of myocardial cell necrosis. This effect of moderate hypothermia on HSP-72 production is shown here for the first time in the setting of cardiac surgery but is supported by previous experimental studies. Indeed, in addition to such commonly accepted activators of the transcription factor heat shock factor 1 as heat, hypoxia, reactive oxygen species, and proinflammatory cytokines, ${ }^{9}$ a few studies have reported that exposure to cold also induces gene expression of HSP-70. ${ }^{15,16}$ In an isolated rat heart model, hypothermic perfusion $\left(31^{\circ} \mathrm{C}\right)$ preceding ischemia led to expression of mRNA encoding HSP-70. ${ }^{13}$ In vivo, however, recovery from hypothermia seems to be necessary for maximal stimulation of HSP-70 expression in response to heat shock factor $1 .{ }^{16}$

A main finding of this study was the presence of HSP-72 in the myocardium as early as 30 minutes after institution of hypothermic $\mathrm{CPB}$, before institution of cold cardioplegic arrest. In contrast to that finding, HSP-72 was detectable only at the end of the period of myocardial ischemia in animals operated on under normothermia. This observation suggests that different kinds of stress induced HSP-72 during the course of cardiac surgery in both animal groups of this series. Indeed, 30 minutes after the beginning of CPB, both esophageal and myocardial temperature were (as expected) lower in the hypothermia than in the normothermia group. At that time, proinflammatory cytokine production is blunted in animals undergoing moderate hypothermic CPB but not in those operated on under normothermia, as we have recently shown. ${ }^{1}$ This indicates the preponderant role of hypothermia in inducing HSP-72 during the early phase of hypothermic CPB. In contrast, proinflammatory mediators such as tumor necrosis factor (TNF) $\alpha$, either released 
A

HSP72

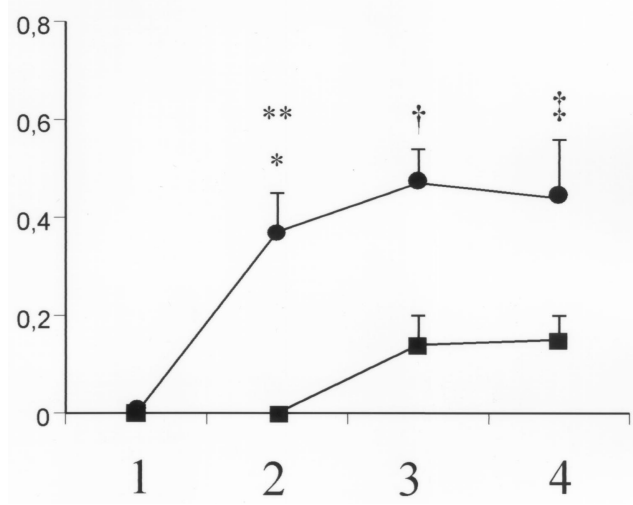

$\mathrm{B}$

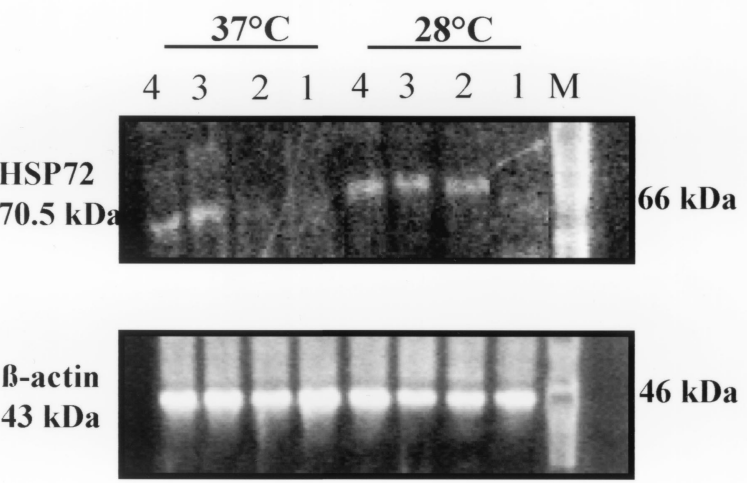

Figure 2. A. Synthesis of HSP-72 measured by Western blot in myocardium before CPB (1), before aortic crossclamping (2), before removal of aortic clamp (3), and 6 hours after CPB (4) in pigs operated on under moderate hypothermia (temperature $28^{\circ} \mathrm{C}$, circles) and under normothermia (temperature $37^{\circ} \mathrm{C}$, squares). Band intensities for HSP-72 were normalized for band intensities of $\beta$-actin. Data points represent mean value; error bars represent SEM. Double asterisk indicates difference versus prebypass value in hypothermia group $(P=.068)$. Asterisk indicates $\boldsymbol{P}=.001$ between groups; dagger indicates $\boldsymbol{P}=.085$; double dagger indicates $\boldsymbol{P}=.058$. B, Effect of core temperature on myocardial expression of HSP-72 detected by Western blot. Results are representative for 8 independent experiments in each group (moderate hypothermia $28^{\circ} \mathrm{C}$, normothermia $37^{\circ} \mathrm{C}$ ). $\mathrm{M}$, Molecular weight markers.

into the circulation or produced in the myocardium during myocardial ischemia, ${ }^{1,2}$ could be responsible for the later induction of HSP-72 in the normothermia group. ${ }^{17}$

Another main finding of this study was the significant reduction of cell death by necrosis but not by apoptosis related to moderately hypothermic CPB. HSP-70 is well known to play a key regulatory role in cell survival, ${ }^{18}$ protecting against cell necrosis. ${ }^{19}$ Our results showing that HSP-72-positive staining was present not only in parenchymatous cells but also in resident macrophages in the myocardium could indicate its inhibitory role on in situ macrophage- and TNF-mediated tissue injury. ${ }^{20}$ Indeed, HSP-70 decreases TNF- $\alpha$ and interleukin $1 \beta$ production by binding nuclear factor $\kappa \mathrm{B}$, preventing its translocation into the nucleus and thus reducing inflammatory response. ${ }^{21} \mathrm{In}$ addition to this, HSP-70 prevents posttranslational release of TNF- $\alpha{ }^{22}$ This could also be a mechanism by which moderate hypothermia blunts TNF- $\alpha$ production during cardiac operations, as we have shown previously. ${ }^{1,2}$

In contrast to their action against necrosis, the role of HSPs in the induction of apoptosis is controversial. Because they refold damaged repressors of the apoptotic pathway or prevent their degradation, HSPs have been implicated in the control of apoptosis. ${ }^{10}$ HSP-70 could also control apoptosis at the level of signal transduction of apoptosis-regulating proteins. ${ }^{23}$ On the other hand, experimental studies have shown that HSPs are also inducers of apoptosis when nonlethal endotoxin stimulation occurs before a stress that normally elicits HSP synthesis. ${ }^{24}$ This points out the importance of quality and sequence of stresses imposed on the investigated organism in determining whether and how the cells will die.

In our series, although synthesis of HSP-72 was significantly higher in pigs operated on under moderate hypothermia than in the other animals, the levels of gene expression of apoptosis-regulatory proteins and amounts of apoptotic cells in the myocardium were similar in the two groups. This clearly indicates that in our model moderate hypothermia did not exert its protective effect by inhibiting apoptotic cell death. It is conceivable that different factors specific for each group of animals (hypothermic vs normothermic CPB) exerted apoptosis-inducing effects. Indeed, hypothermia itself is an inducer of apoptosis by inducing expression of the tumor suppressor protein $\mathrm{p} 53$, a temperature-sensitive protein. ${ }^{25}$ On the other hand, proinflammatory cytokines released during normothermic $\mathrm{CPB}^{2,26}$ are inducers of apoptosis in various cell types. ${ }^{9}$ TNF- $\alpha$ upwardly regulates Fas expression and stimulates its type 1 receptor, inducing apoptotic events. ${ }^{27}$ In addition, the anti-inflammatory cytokine interleukin 10, the circulating levels of which are increased in the early phase of hypothermic CPB as we have recently shown, ${ }^{1}$ is an inducer of apoptosis in patients with sepsis and is thought to contribute to organ protection by enhancing the elimination of activated leukocytes. ${ }^{28}$

It has recently been suggested that the presence of HSP-70 at the protein level is necessary for the inhibition of 


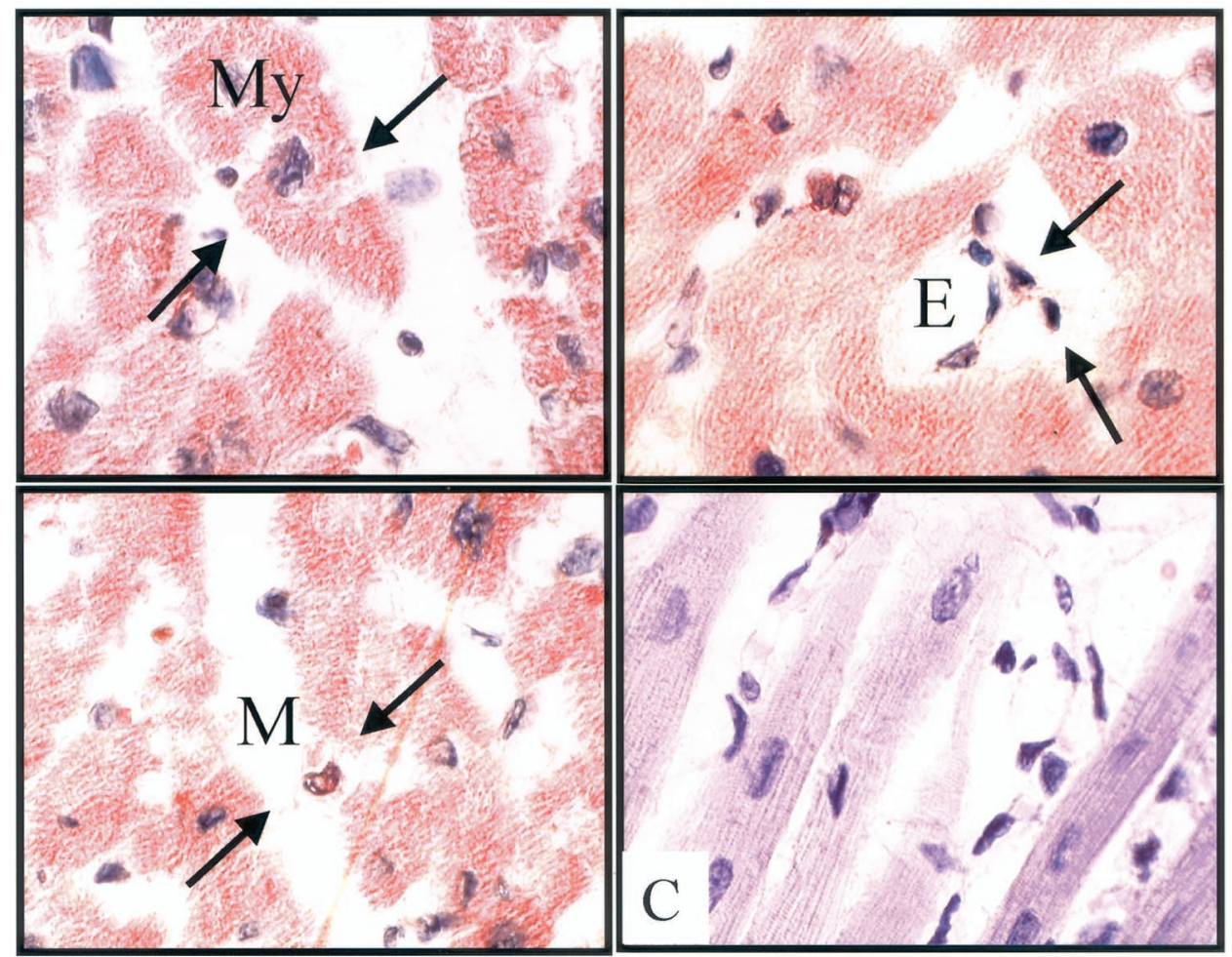

Figure 3. Example of immunohistochemical study (original magnification $1000 \times$ ) of right ventricular myocardium taken 6 hours after CPB in representative animal operated on under hypothermia showing the presence of HSP-72 (red staining) within myocardial cells (My, arrows), endothelial cells (E, arrows), and resident macrophages (M, arrows). C, Control probe taken before CPB.

TABLE 3. Effect of core temperature during CPB on intramyocardial gene expression of apoptosis regulatory proteins

\begin{tabular}{lccc}
\hline & Hypothermia $\left(\mathbf{2 8}^{\circ} \mathbf{C}\right)$ & Normothermia $\left(\mathbf{3 7}^{\circ} \mathbf{C}\right)$ & $\boldsymbol{P}$ value \\
\hline Bcl-xL & $0.42 \pm 0.05$ & $0.28 \pm 0.15$ & $>.2$ \\
Bak & $0.25 \pm 0.1$ & $0.12 \pm 0.08$ & $>.2$ \\
Fas & $0.50 \pm 0.12$ & $0.67 \pm 0.16$ & $>.2$ \\
\hline
\end{tabular}

Results (mean \pm SEM) are shown as the ratio of apoptosis-regulating protein mRNA to $\beta$-actin mRNA.

apoptosis and that the apoptosis-promoting protein Fas leads in turn to inhibition of the heat shock factor 1 and HSP-70 stress response. ${ }^{29}$ However, there is usually a lack of linear correlation between the presence of HSPs and their protective role, indicating that a critical amount of HSP is necessary to elicit a protective effect. ${ }^{30}$ Our results confirm this and show a relationship between overexpression of HSP-72 and reduction of cell death by necrosis.

In conclusion, in this study moderate hypothermic $\mathrm{CPB}$, as compared with normothermic $\mathrm{CPB}$, enhanced gene expression and synthesis of HSP-72 and reduced cell death by necrosis. Upward regulation of HSP-72 could be a mecha- nism by which moderate hypothermia during cardiac operations protects against organ damage.

\section{References}

1. Qing M, Vazquez-Jimenez JF, Klosterhalfen B, Sigler M, Schumacher $\mathrm{K}$, et al. Influence of temperature during cardiopulmonary bypass on leukocyte activation, cytokine balance, and post-operative organ damage. Shock. 2001;15:372-7.

2. Vazquez-Jimenez JF, Qing M, Hermanns B, Klosterhalfen B, Woltje M, Chakupurakal R, et al. Moderate hypothermia during cardiopulmonary bypass reduces myocardial cell damage and myocardial cell death related to cardiac surgery. J Am Coll Cardiol. 2001;38:1216-23.

3. Denecker G, Vercammen D, Declercq W, Vandenabeele P. Apoptotic and necrotic cell death induced by death domain receptors. Cell Mol Life Sci. 2001;58:356-70.

4. Thompson CB. Apoptosis in the pathogenesis and treatment of disease. Science. 1995;267:1456-62.

5. Savill JS, Wyllie AH, Henson JE, Walport MJ, Henson PM, Haslett C. Macrophage phagocytosis of aging neutrophils in inflammation: programmed cell death in the neutrophil leads to its recognition by macrophages. J Clin Invest. 1989;83:865-75.

6. Nagata S. Apoptosis by death factor. Cell. 1997;88:355-65.

7. Muzio M, Salvesen GS, Dixit VM. FLICE induced apoptosis in a cell-free system: cleavage of caspase zymogens. J Biol Chem. 1997; 272:2952-6.

8. Oltvai ZN, Milliman CL, Korsmeyer SJ. Bcl-2 heterodimerizes in vivo with a conserved homolog, Bax, that accelerates programmed cell death. Cell. 1993;74:609-19. 
9. Benjamin IJ, McMillan DR. Stress (heat shock) proteins: molecular chaperones in cardiovascular biology and disease. Circ Res. 1998;83: 117-32.

10. Wong HR, Mannix RJ, Rusnak JM, Boota A, Zar H, Watkins SC, et al. The heat-shock response attenuates lipopolysaccharide-mediated apoptosis in cultured sheep pulmonary artery endothelial cells. Am J Respir Cell. Mol Biol 1996;15:745-51.

11. Hall TJ. Role of hsp70 in cytokine production. Experientia. 1994;50: 1048-53.

12. Craig EA. Essential roles of $70 \mathrm{kDa}$ heat inducible proteins. Bioessays. 1989;11:48-52.

13. Ning $\mathrm{XH}, \mathrm{Xu} \mathrm{CS}$, Portman MA. Mitochondrial protein and HSP70 signaling after ischemia in hypothermic-adapted hearts augmented with glucose. Am J Physiol 1999;277(1 Pt 2):R11-7.

14. Gujral JS, Bucci TJ, Farhood A, Jaeschke H. Mechanism of cell death during warm hepatic ischemia-reperfusion in rats: apoptosis or necrosis? Hepatology. 2001;33:397-405.

15. Liu AY, Bian H, Huang LE, Lee YK. Transient cold shock induces the heat shock response upon recovery at 37 degrees $\mathrm{C}$ in human cells. J Biol Chem. 1994;269:14768-75.

16. Cullen KE, Sarge KD. Characterization of hypothermia-induced cellular stress response in mouse tissues. J Biol Chem. 1997;272:1742-6.

17. Klosterhalfen B, Hauptmann S, Offner FA, Amo-Takyi B, Tons C, Winkeltau $\mathrm{G}$, et al. Induction of heat shock protein 70 by zinc-bis(dl-hydrogenaspartate) reduces cytokine liberation, apoptosis, and mortality rate in a rat model of LD100 endotoxemia. Shock. 1997;7: 254-62.

18. Chu EK, Ribeiro SP, Slutsky AS. Heat stress increases survival rates in lipopolysaccharide-stimulated rats. Crit Care Med. 1997;25:172732 .

19. Vayssier M, Banzet N, Francois D, Bellmann K, Polla BS. Tobacco smoke induces both apoptosis and necrosis in mammalian cells: differential effects of HSP70. Am J Physiol. 1998;275:L771-9.

20. Meng X, Brown JM, Ao L, Nordeen SK, Franklin W, Harken AH, et al. Endotoxin induces cardiac HSP70 and resistance to endotoxemic myocardial depression in rats. Am J Physiol. 1996;271:C1316-24.
21. Yoo CG, Lee S, Lee CT, Kim YW, Han SK, Shim YS. Anti-inflammatory effect of heat shock protein induction is related to stabilization of I kappa B alpha through preventing I kappa B kinase activation in respiratory epithelial cells. J Immunol. 2000;164:5416-23.

22. Ribeiro SP, Villar J, Downey GP, Edelson JD, Slutsky AS. Effects of the stress response in septic rats and LPS-stimulated alveolar macrophages: evidence for TNF-alpha posttranslational regulation. Am J Respir Crit Care Med. 1996;154:1843-50.

23. Mosser DD, Caron AW, Bourget L, Denis-Larose C, Massie B. Role of the human heat shock protein hsp70 in protection against stressinduced apoptosis. Mol Cell Biol. 1997;17:5317-27.

24. Xu DZ, Lu Q, Swank GM, Deitch EA. Effect of heat shock and endotoxin stress on enterocyte viability apoptosis and function varies based on whether the cells are exposed to heat shock or endotoxin first. Arch Surg. 1996;131:1222-8.

25. Matijasevic Z, Snyder JE, Ludlum DB. Hypothermia causes a reversible, p53-mediated cell cycle arrest in cultured fibroblasts. Oncol Res. 1998;10:605-10.

26. Menasche P, Haydar S, Peynet J, Du BC, Merval R, Bloch G, et al. A potential mechanism of vasodilation after warm heart surgery: the temperature-dependent release of cytokines. J Thorac Cardiovasc Surg. 1994;107:293-9.

27. Spanaus KS, Schlapbach R, Fontana A. TNF-alpha and IFN-gamma render microglia sensitive to Fas ligand-induced apoptosis by induction of Fas expression and down-regulation of Bcl-2 and Bcl-xL. Eur J Immunol. 1998;28:4398-08.

28. Keel M, Ungethum U, Steckholzer U, Niederer E, Hartung T, Trentz $\mathrm{O}$, et al. Interleukin-10 counterregulates proinflammatory cytokineinduced inhibition of neutrophil apoptosis during severe sepsis. Blood. 1997;90:3356-63.

29. Schett G, Steiner CW, Groger M, Winkler S, Graninger W, Smolen J, et al. Activation of Fas inhibits heat-induced activation of HSF1 and up-regulation of hsp70. FASEB J. 1999;13:833-42.

30. Donnelly TJ, Sievers RE, Vissern FL, Welch WJ, Wolfe CL. Heat shock protein induction in rat hearts: a role for improved myocardial salvage after ischemia and reperfusion? Circulation. 1992;85:769-78. 